\title{
The Impact of the use of Modern Teaching Technologies (MTT) In Educational Process at the Faculty of Education, Jazan University Mahasin Gad Alla Mohamed
}

Educational Technology Department, Jazan University, Sabya, Jazan, Kingdom Saudi Arabia

\begin{abstract}
The purpose of this study was to investigate the use of Modern Teaching Technologies (MTT) among faculty staff members at the Faculty of Education, Jazan University. The study conducted in the academic year 2016. A Systematic random sample of (130) faculty staff members was used. The faculty staff members were asked to express their attitudes towards the use of modern teaching technologies in educational processes. A questionnaire was used for collecting data. The data analyzed with SPSS personal computer program. Appropriate statistics for description (frequencies, percentage, means, standard deviations, T-Test and ANOVA Test) were used. The results showed that: There were significant differences at the level of significance $(0.05)$ between faculty staff responses on the impact of the use of modern teaching technologies in the educational process in favor of male participants. Thus, the null hypothesis (H0: $\mu 1=\mu 2)$ was rejected; There were significant differences at the level of significance $(0.05)$ between the study participants attitudes towards the use of modern teaching technologies in the educational process, related to experience variable. Thus, The null hypothesis was rejected; There were no significant differences at the level of significance (0.05) between the study participants attitudes towards the use of modern teaching technologies in the educational process, related to computer training courses. Thus, the null hypothesis (H0) was accepted. The researcher concluded that faculty staff members have a positive attitude towards the use of modern teaching technologies in the educational process. The researcher, also, stated some recommendations.
\end{abstract}

Keywords : Faculty staff Members, Modern Teaching Technologies (MTT), Faculty of Education, Jazan University.

\section{INTRODUCTION}

Modern teaching technologies have been part of the teaching and learning environment. It is one of the resources that teachers use to help facilitate student learning. The increasing variety and accessibility of modern teaching technologies have expanded the tools and the opportunities teachers have to use technology. Computer devices are more powerful and come in different forms, from those that sit on our desks to those that sit in the palm of our hands. The internet connects those devices and connects students to each other in the classroom, through the school, and around the world. Technological devices and networks have changed schools and classrooms (Eady \& Lockyer, 2013).

The important role of modern teaching technologies play in education gives teachers the opportunity to design meaningful learning experiences that embed technology. Teachers always considered the tools and resources that can best support learning activities for 
their students. However, advances and accessibility of modern teaching technologies have made the possibilities seem almost endless (Cuban, 2003).

It is important for teachers to embed technology appropriately in teaching and learning processes. A teacher has many considerations in designing the appropriate use of modern teaching technologies in educational process. Teachers have to keep up to date with the technological tools that are available to them (ibid).

Making modern teaching technologies available in schools does not mean that teachers will make use of them, so it is necessarily for teacher to use them effectively in educational process (ibid).

Teachers can embed modern teaching technologies into students activities, such as word-processing, presentation and publishing software, webpage authoring tools, email, and online discussion. These technologies allow students to communicate with their teachers as well as with each other using text, images, sound, and video (Eady \& Lockyer, op. cit.).

Is it true that not all teachers are embedding technology into their teaching? A significant body of research has investigated why this occurs. Teachers face many difficulties in using technology in the classroom, such as lack of resources, technophobia, and lack of training programs in the use of technology in teaching. Some resource barriers are being overcome with an increasing number of computers and software applications and faster, more reliable networks in schools. Teachers will avoid using technology if it does not work properly or there is a lack of technical support in their school. Teachers also need training programs on new technology tools that they can use in their teaching. The important factors in the use of technology in the classroom, are teacher knowledge and skills. Lack of specific technical skills is a common reason teachers give for not using technology (Hew \& Brush, 2007).

However, teachers who undertake training programs to build skills through professional development activities are much more likely to integrate technology into their teaching than those who do not (Mueller et al., 2008).

Modern teaching technologies are an inevitable part of society, that cause teachers to consider the implications for them in their role as teachers and as lifelong learners themselves. This does not mean that teachers naturally understand how to use those technologies appropriately. The challenge for teachers is to draw upon their continually developing knowledge and skills about what to teach and how to teach (Eady \& Lockyer, op. cit.).

If teachers understand the importance of integrating modern technology into their classrooms and receive the professional development needed in their fields, they could become accustomed to using technology tools; therefore, student learning and motivation could increase (Young, 2008).

Although e-mail is well established in undergraduate education, it is not fully integrated into the curriculum. E-mail and computing often limit to courses that focus on a necessary tool, such as computer programming or statistics courses. Using email in the undergraduate curriculum as an instructional tool is still relatively new, but introducing e-mail into any curriculum has many potential benefits (Hassett, et al. 1995).

Students and teachers both benefit from using e-mail. Using e-mail as one of the modern technologies is the first step in using the Internet, in research and 
education. Students who use e-mail find that teachers are accessible for more than office hours. E-mail extends office hours to virtually any time and place, to the mutual convenience of faculty and students. (ibid).

E-mail allows students and teachers to join with each other and students themselves and other learners, from all over the globe, in discussions of mutual educational interest. This enlarged "peer group" brings together people from other cultures, religions, educational systems, and political systems, enriching students on the local campus (ibid).

Internet use in classrooms helps both teachers and students to share information with each other, to discuss the opinions of other users, and to communicate with people from different locales in common interest areas. Internet use helps students, acquire the skills needed for searching and researching without guided instruction. Appropriate classroom techniques can help students acquire skills and desired behavior more efficiently (Sezer, 2010).

Using email as an educational tool can create a healthy academic atmosphere via better interaction between the staff member and student, and students themselves (Sadat \& Rahman, 2015).

Internet and websites provide information in different areas through the use of words, pictures, illustrations, voices, and images. This information is offered to an unlimited number of users over the world with low costs in virtual platforms, making the web an unrivalled form of entertainment and consumption (Lateh \& Raman, 2005).

Dreaweesh (2003) study was conducted to examined the differences between the second-grade students in the achievement of the science subject by means of a multimedia program and the traditional method of teaching at the levels of (remember, understanding, application), in the Bloom Taxonomy, of each individual. The sample was randomly selected (control group and experimental group). The researcher has built a test of achievement in the light of the content and has been verified the validity and stability. The study concluded the following results:

There were no significance differences at the level of significance (0.05) between the average of the experimental group and the control group in the premeasurement of the achievement level, in the light of the Bloom Taxonomy (remember, understanding, application), indicating the homogeneity of the experimental and control groups and similar before the procedure Experience.

There were significant differences at the level of significance (0.05) between the experimental group and the control group average in the postmeasurement of the achievement level in the light of the Bloom classification (remember, understand, application) in the favor of the experimental group.

Al-Nadawi (2012) studied the importance of using educational techniques and their role in developing methodologies of physical education and their importance in choosing and organizing the method followed. The researcher hypothesized a statistically significant relationship between the use of educational techniques and developing physical education methodologies. The researcher made a (26) items survey after shown on a panel of experts. The study sample was (23) teachers at the Colleges and departments with physical education methodologies at the University of Mosul. The researcher concluded that, educational techniques have an important role in choosing and organizing the desired methodology. The researcher recommended that, the necessity of 
using teaching aids by the teaching or the educational techniques that coincides with the content and goals of the lesson and the necessity of verifying educational techniques to make them more useful and interesting.

Also, Al-Ajlooni (2009) set up a study to examine the reality of ICT in the Faculty of Educational Sciences at the University of Jordan, the availability of infrastructure, the extent of use by graduate students in the college, and the obstacles to use. The study sample were all the graduate students in the Faculty of Educational Sciences at the University of Jordan who registered during the second semester of the academic year 2006/2007. The study sample was (819) students, distributed to (551) master students and (302) Ph.D. students. A questionnaire was used for collecting data. The results showed that the development of computer tools and devices available in the computer labs in the Faculty of Educational Sciences is good in number and proportion; the laboratories of the Faculty of Educational Sciences possess software with general objectives. The main obstacle facing the use of ICTs is the lack of hardware in computer labs, the low speed of data processing devices, the large number of students in one subject, the lack of software programs, and the lack of adequate training for faculty members on the use of the Internet. The results did not reveal any significant differences at the level $(0.05=\alpha)$ in the degree of the use of postgraduate students in information technology related to gender and degree (M.Sc., Ph.D.).

Nagel (2018) study examined the use of teaching technologies in the classroom among the teacher at Mid-America Nazarene University. The study sample was (1000) teachers who've been in the profession for a minimum of five years. The result indicated that teachers are most positive about technology in the classroom, it also makes students more productive, and it stimulates students more intellectually. The teaching technologies brought the classroom into the modern era and enhanced learning and teaching.

The study of Al-Fahmi (2012) aimed to Recognize the importance of using e-learning in teaching social subjects from the point of view of secondary school teachers in Macca city, Saudi Arabia. A descriptive study approach was used. The study population contained all the teachers of the social subjects in Mecca that reached (190) teachers. A random sample from the study population (110) was chosen. A questionnaire was used as study Techniques. The data were analysed by SPSS program. The statistical analysis included: the mean, Standard Deviation, TTest, Variance Analysing. The study showed the following results: There were significant differences at the level (0.05) relating the importance of using the electronic teaching in teaching the social subjects in favor of the variable (years of experience); There were no significant differences at the level of significance (0.05) between the average of the degree of the studied sample relating the importance of using the electronic teaching in teaching the social subjects. There were significant differences at the level (0.05) relating the usage for the teachers who have training courses, relating the difficulties in using it in favor of the teachers who do not have training courses; There were no significant differences at the level (0.05) between the average of the degree of the studied sample relating the importance of using the electronic teaching in teaching the social subjects according to their knowledge of using the computer; There were significant differences at the level (0.05) relating the usage for the teachers who know how to use the computer, relating the difficulties in using it in favor of the teachers who do not know how to use the computer. In light of the results of the study, the researcher recommended the following: The 
necessity for the competent authorities to adopt electronic teaching project and apply it in schools. The researcher also provided many relevant suggestions to the current study.

In the same way, Mohamed (2013) conducted a study to investigate the attitudes of faculty members at the Faculty of Education Hantoub towards the use of elearning methods and techniques and their relationship with gender, academic level and years of experience. In order to know these trends, the researcher constructed a questionnaire and verified its validity. The researcher used the descriptive analytical method. The study concluded that there were positive attitudes towards the use of e-learning methods and techniques. There were statistically significant differences between male and female attitudes in favor of males, and there were no differences attributable to academic level and years of experience.

\section{METHODS AND MATERIAL}

\section{Sample and Data Collection}

The sample of the study consisted of (130) subjects, who had been chosen from the population of faculty staff members who teach in different programs in the College of Education at Jazan University.

The sample had been selected from the study population by using a systematic random sample. A Questionnaire was used for collecting data. The researcher had measured the validity and reliability of the questionnaire by using: Pearson Correlation Coefficient and Cronbach Alpha Coefficient. The researcher had used Likert Scale. A typical threelevel Likert item had been used in the questionnaire, the three-level Likert item as follows: (Agree), (to some extent), (Disagree). The data were analyzed with SPSS personal computer program.

\section{Analysing Data}

All data were analyzed with the SPSS personal computer program. Appropriate statistics for description (frequencies, percentage, means, standard deviations, T-Test and ANOVA Test) were used.

The hypotheses

1- There are positive attitudes in faculty staff responses towards the use of modern teaching technologies in the educational process.

2- There are no significant differences at the level of significance $(0.05)$ between faculty staff responses on the impact of the use of modern teaching technologies in the educational process, related to gender variable.

$$
\begin{aligned}
& \text { H0: } \mu 1=\mu 2 \\
& \text { HA: } \mu 1 \neq \mu 2
\end{aligned}
$$

3- There are no significant differences at the level of significance (0.05) between faculty staff responses on the impact of the use of modern teaching technologies in the educational process, related to experience variable.

$$
\begin{aligned}
& \text { H0: } \mu 1=\mu 2=\mu 3 \\
& \text { HA: } \mu 1 \neq \mu 2 \neq \mu 3
\end{aligned}
$$

4- There are no significant differences at the level of significance (0.05) between faculty staff responses, related to computer training course variable.

$$
\begin{aligned}
& \text { H0: } \mu 1=\mu 2=\mu 3 \\
& \text { HA: } \mu 1 \neq \mu 2 \neq \mu 3
\end{aligned}
$$

(or at least two means are not equal)

\section{III.RESULTS AND DISCUSSION}

\section{Research participants}

The research participants consisted of (130) faculty staff members, who participated in this study and filled out and submitted the questionnaire. All 
participants were members of the faculty of education, Jazan University. Information pertaining to the personal and vocational details of the study group is given in Table (1).

TABLE (1): PERSONAL DATA OF FACULTY STAFF MEMBERS

\begin{tabular}{llccc}
\hline No & Variable & $\begin{array}{c}\text { Variable } \\
\text { Type }\end{array}$ & $\begin{array}{c}\text { Frequency } \\
(\mathrm{F})\end{array}$ & $\%$ \\
\hline 1. & Gender & Male & 21 & 16.2 \\
& & Female & 109 & 83.8
\end{tabular}

Education
Level

Bachelor

2

1.5

Master

42

32.3

Science

Ph.D.

86

3. Specialization

Science

75

Arts

55

4. Background

Education

Non-

84

84

Education

5. Occupation

$\begin{array}{cc}\text { Teaching } & 2 \\ \text { Assistant } & \\ \text { Lecturer } & 42 \\ \text { Assistant } & 70 \\ \text { Professor } & \\ \text { Associate } & 12 \\ \text { Professor } & \\ \text { Professor } & 4 \\ \text { Less than 5 } & 41 \\ \text { years } & \\ \text { 5-10 years } & 21 \\ \text { More than } & 68 \\ \text { 10 years } & \end{array}$

7. Computer

No training

16

Training

$\begin{array}{ll}\text { courses } & \\ \text { One } & 22 \\ \text { training } & \\ \text { course } & \\ \text { Two } & 31 \\ \text { training } & \\ \text { courses } & \\ \text { More than } & 61\end{array}$

\begin{tabular}{|c|c|c|c|c|}
\hline No & Variable & $\begin{array}{c}\text { Variable } \\
\text { Type }\end{array}$ & $\begin{array}{l}\text { Frequency } \\
\text { (F) }\end{array}$ & $\%$ \\
\hline \multicolumn{5}{|c|}{ two } \\
\hline 8. & $\begin{array}{c}\text { Technology } \\
\text { Training }\end{array}$ & $\begin{array}{c}\text { No training } \\
\text { courses }\end{array}$ & 29 & 22.3 \\
\hline 9. & & $\begin{array}{c}\text { One } \\
\text { training } \\
\text { course }\end{array}$ & 25 & 19.2 \\
\hline 10. & & $\begin{array}{c}\text { Two } \\
\text { training } \\
\text { courses }\end{array}$ & 29 & 22.3 \\
\hline 11. & & $\begin{array}{l}\text { More than } \\
\text { two }\end{array}$ & 47 & 36.2 \\
\hline
\end{tabular}

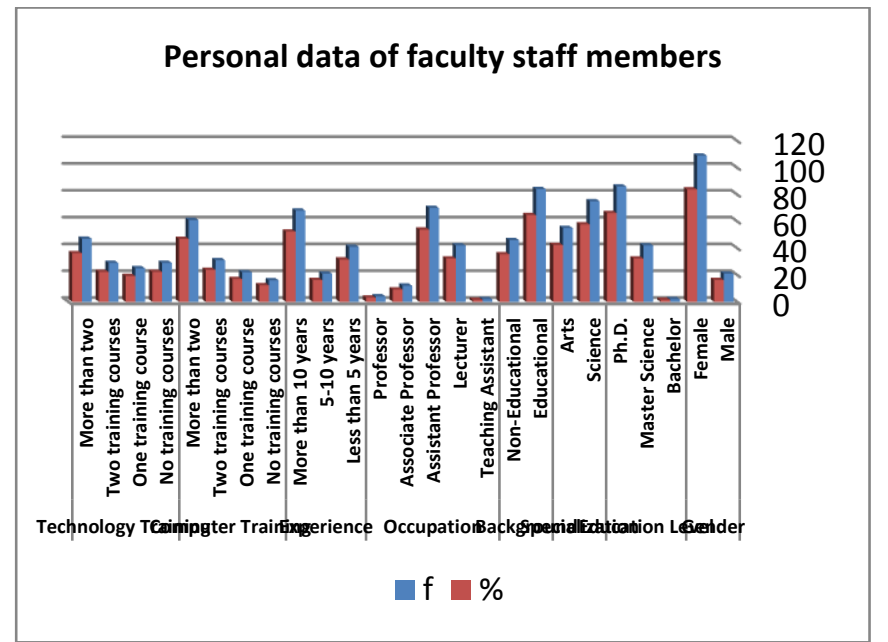

Figure (1): Personal Data of Faculty Staff Members

3.1 Table (1) and Figure (1) showed that (16.2\%) (f: 21) 31.5 of the study participants were male, with (83.8\%) (f: 109) female. In review of education level correlation, 16.2 Ph.D. is the largest group (66.2\%) (f: 86), master 52.3 science is the second largest (32.3\%) (f: 42) and bachelor is third largest (1.5\%) (f: 2). In review of specialization correlation, science is the largest group (57.2\%) (f: 75), arts is the second largest (42.3\%) (f: 55). In the term of education background correlation, education is the largest group (64.6\%) (f: 84), noneducation is the second largest (35.4\%) (f: 46). In review of occupation correlation, assistant professor is the largest group (53.8\%) (f: 70), lecturer is the second largest (32.3\%) (f: 42), associate professor is 
third largest (9.2\%) (f: 12), professor is the fourth largest (3.1\%) (f: 4), and teaching assistant is the fifth largest (1.5\%) (2). In terms of experience correlation, the largest group has more than 10 years' experience (52.3\%) (f: 68), the second largest group has less than 5 years' experience (31.5\%) (f: 41), while those with 5 to 10 years' experience is the third largest $(16.2 \%)$ (f: 21). In review of correlation of computer training programs, those who attended more than two training courses are in the largest group (46.9\%) (f: $61)$, those who attended two training courses are in the second largest (23.8\%) (f: 31), those who attended one training course are in the third largest (16.9\%) (f: 22 ), and those who not attended any training courses are in the fourth largest (12.3\%) (f: 16). In the term of correlation of technology training programs, those who attended more than two training courses are in the largest group (36.2\%) (f: 47), those who attended two training courses, and who not attended any training courses are in the second largest (22.3\%) (f: 29 ), and those who attended one training course are in the third largest (19.2\%) (f: 25).

The first hypothesis : There are positive attitudes in faculty staff responses towards the use of modern teaching technologies in the educational process.

To verify this hypothesis the questionnaire was divided to five aspects, each aspect consisted of a number of items. Mean and Std. Deviation values for each item were calculated.

\section{Questionnaire Aspects}

The first aspect: Culture of using modern teaching technology

The first aspect consisted of twelve items (1, 3-4, 6-7, 9, 11, 13, 17, and 25-27). Mean and standard deviation for the first aspect items (Faculty staff culture on using modern teaching technology) were analysed. Table (2) displayed the mean and standard deviation analysis.

Table (2) : Mean and Standard Deviation Analysis for Faculty Staff Culure On Using MTT

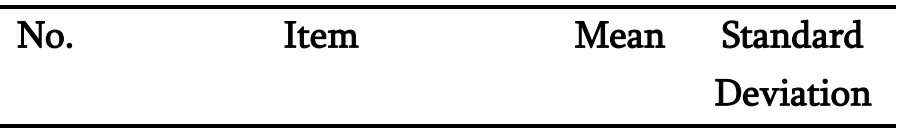

\begin{tabular}{llll}
\hline 1. & Computer is one of the & 2.95 & 0.23 \\
basics modern teaching & & \\
technologies
\end{tabular}

2. Computer learning is $\quad 2.96 \quad 0.19$ essential for every faculty member

3. I am proficient in dealing $\quad 2.68 \quad 0.48$ with computers

4. I need training for using $\quad 1.89 \quad 0.83$ the presentation program

5. It is important to $\quad 2.92 \quad 0.31$ constantly train on the latest presentation software

6. I'm good in using $\quad 2.84 \quad 0.40$ Microsoft Word program

7. Learning the Internet is $2.97 \quad 0.17$ essential for every faculty member

8. I have the skill of $\quad 2.78 \quad 0.47$ searching through the internet

9. I need training in using e- $\quad 1.85 \quad 0.81$ mail in the learning process

10. I can connect the data $\quad 2.38 \quad 0.76$ projector to the computer easily

11. I have the knowledge of $\quad 2.50 \quad 0.66$ running the data projector 


\begin{tabular}{llcc}
\hline No. & \multicolumn{1}{c}{ Item } & Mean & $\begin{array}{c}\text { Standard } \\
\text { Deviation }\end{array}$ \\
\hline 12. & $\begin{array}{l}\text { I face difficulties in } \\
\text { adjusting the data } \\
\text { projector with the } \\
\text { computer }\end{array}$ & 1.72 & 0.72 \\
\hline
\end{tabular}

Table (2) showed values of standard deviation \& Mean for the study sample culture on using MTT. The biggest mean value (2.97) and standard deviation (0.17) is for participants who see the learning of the Internet is essential for the faculty member. The second biggest mean value (2.96) and standard deviation (0.19) is for those who see the computer learning is essential for the faculty staff. The third biggest mean value (2.95) and standard deviation (0.23), is for the participants who see computer is one of the basics modern teaching technologies. The fourth biggest mean (2.92) and standard deviation $(0.31)$ is for the participants who see constantly training on the latest presentation software is important for faculty staff members. The fifth biggest mean (2.84) and standard deviation (0.40) is for the participants who have the skill of using Microsoft Word application programs. The sixth biggest mean (2.78) and standard deviation (0.47) is for the participants who have the skill of searching through the internet. The seventh biggest mean (2.68) and standard deviation (0.48) is for the participants who are proficient in dealing with computers. The eighth biggest mean (2.50) and standard deviation (0.66) is for the participants who have the knowledge of running the data projector. The Ninth biggest mean (2.38) and standard deviation (0.76) is for the participants who can connect the data projector to the computer easily. The Tenth biggest mean (1.89) and standard deviation (0.76) is for the participants who need training for using the presentation program. The eleventh biggest mean (1.85) and standard deviation (0.81) is for the participants who need training in using e-mail in the learning process. The twelfth biggest mean (1.72) and standard deviation (0.72) is for the participants who face difficulties in adjusting the data projector with the computer.

It is clear from the above that the faculty staff members at the college of education, Jazan university have the culture of using modern teaching technology in educational process.

\section{The second aspect: Reality of use of modern teaching technologies in educational process}

The reality of use of modern teaching technologies in teaching consisted of nine questionnaire items $(2,5$, $8,18-19,21,31,37,38)$. Mean and standard deviation for the second aspect items (Reality of use of modern teaching technologies in educational process) were analysed. Table (3) displayed the mean and standard deviation analysis.

Table (3): Mean And Standard Deviation Analysis of The Reality of Use Of MTT

\begin{tabular}{llcc}
\hline No. & \multicolumn{1}{c}{ Item } & Mean & $\begin{array}{c}\text { Standard } \\
\text { Deviation }\end{array}$ \\
\hline 1. & $\begin{array}{l}\text { I use computer in teaching } \\
\text { process }\end{array}$ & 2.91 & 0.29
\end{tabular}

2. The use of computers helps $\begin{array}{lll}\text { students to learn problem } \quad 2.75 & 0.43\end{array}$ solving skills

3. I use the presentation program in preparing my $\quad 2.54 \quad 0.65$ lectures

4. I received students' assignments via email

5. I use email as a communication channel between me and my $1.89 \quad 0.81$ students

6. I have a website $2.35 \quad 0.93$ 


\begin{tabular}{llcc}
\hline No. & \multicolumn{1}{c}{ Item } & Mean & $\begin{array}{c}\text { Standard } \\
\text { Deviation }\end{array}$ \\
\hline 7. & $\begin{array}{l}\text { I prefer to use modern } \\
\text { teaching technologies in } \\
\text { teaching my courses }\end{array}$ & 2.67 & 0.60 \\
8. $\quad \begin{array}{l}\text { I can reach my students to } \\
\text { the degree of mastery } \\
\text { without the use of modern } \\
\text { teaching technologies }\end{array}$ & 2.02 & 0.83 \\
9. $\quad \begin{array}{l}\text { The traditional teaching } \\
\text { method gives better results } \\
\text { than using modern } \\
\text { teaching technologies }\end{array}$ & 1.61 & 0.74 \\
\hline
\end{tabular}

Table (3) showed values of standard deviation \& Mean for the study sample reality of use of MTT. The biggest mean value (2.91) and standard deviation (0.29) is for participants who are using computer in teaching process. The second biggest mean value (2.75) and standard deviation (0.43) is for participants who see that, the use of computers helps students to learn problem solving skills. The third biggest mean value (2.67) and standard deviation (0.60), is for those who prefer to use modern teaching technologies in their classrooms. The fourth biggest mean (2.54) and standard deviation (0.65) is for the participants who use the presentation program in preparing their lectures. The fifth biggest mean (2.35) and standard deviation (0.93) is for the participants who have websites. The sixth biggest mean (2.02) and standard deviation (0.83) is for the participants who mentioned that, they can reach the student to the degree of mastery without the use of modern teaching technologies. The seventh biggest mean (1.89) and standard deviation (0.81) is for the participants who use email as a communication channel between them and their students. The eighth biggest mean (1.65) and standard deviation (0.82) is for the participants who received students' assignments via email. The ninth biggest mean (1.61) and standard deviation (0.74) is for the participants who see that, the traditional teaching method gives better results than modern teaching technologies.

According to the results of the study, the faculty staff members have positive attitudes towards the reality of use of modern technologies in educational process, except for reach the student to the degree of mastery without the use of modern teaching technologies (34.6\%) (f: 45) of the participants answered with (Agree) which approximately similar to (33.1\%) (f: 43) who answered with (Disagree), receiving students' assignments via email (56.9\%) (f: 74) answered with (Disagree), while only (21.5\%) (f: 28) answered with (Agree), using email as a communication channel between them and their students (39.2\%) (f: 51) answered with (Disagree), while only (27.7\%) (f: 36) answered with (Agree), and who prefer traditional teaching methods than using modern technologies (54.6\%) (f: 71) answered with (Disagree), while only (15.4\%) (f: 20) answered with (Agree).

\section{The third aspect: The benefit of modern teaching technologies to faculty staff and student}

The benefit of modern teaching technologies to faculty staff and student consisted of nine questionnaire items (15-16, 19, 22-23, 30, 33-34, 36). Mean and standard deviation for the third aspect items (The benefit of modern teaching technologies to faculty staff and student) were analysed. Table (4) displayed the mean and standard deviation analysis. 
Table (4): Mean and Standard Deviation Analysis of The Benefit of MTT to Faculty Staff

\begin{tabular}{|c|c|c|c|}
\hline No. & Item & Mean & $\begin{array}{l}\text { Standard } \\
\text { Deviation }\end{array}$ \\
\hline 1. & $\begin{array}{l}\text { I'm asking my students to } \\
\text { search for some } \\
\text { information through the } \\
\text { Internet }\end{array}$ & 2.60 & 0.59 \\
\hline 2. & $\begin{array}{l}\text { I urge my students to make } \\
\text { use of the information } \\
\text { available on the Internet }\end{array}$ & 2.77 & 0.45 \\
\hline 3. & $\begin{array}{l}\text { On my website I upload } \\
\text { lectures and information } \\
\text { that benefit the student }\end{array}$ & 1.56 & 0.78 \\
\hline 4. & $\begin{array}{l}\text { I often urge my students to } \\
\text { browse my website }\end{array}$ & 1.73 & 0.83 \\
\hline 5. & $\begin{array}{l}\text { The use of modern } \\
\text { teaching technologies } \\
\text { facilitates student's } \\
\text { understanding }\end{array}$ & 2.85 & 0.40 \\
\hline 6. & $\begin{array}{l}\text { E-learning techniques help } \\
\text { students connect } \\
\text { theoretical and practical } \\
\text { concepts }\end{array}$ & 2.74 & 0.46 \\
\hline 7. & $\begin{array}{l}\text { Modern teaching } \\
\text { technologies help students } \\
\text { to develop their creative } \\
\text { skills }\end{array}$ & 2.77 & 0.45 \\
\hline
\end{tabular}

Table (4) showed values of standard deviation \& Mean for the study sample benefit of modern teaching technologies. The biggest mean value (2.85) and standard deviation (0.40) is for participants who see that the use of modern teaching technologies facilitates student's understanding. The second biggest mean value (2.77) and standard deviation $(0.45)$ is participants who are urging their students to make use of the information available on the Internet, and, also, who see that the modern teaching technologies help students to develop their creative skills. The third biggest mean value (2.74) and standard deviation (0.46), is for those who see the elearning techniques help students in connecting theoretical and practical concepts. The fourth biggest mean (2.60) and standard deviation (0.59) is for the participants who are asking their students to search for some information through the Internet. The fifth biggest mean (1.73) and standard deviation (0.83) is for the participants who often urge their students to browse their website. The sixth biggest mean (1.56) and standard deviation (0.78) is for the participants who uploaded their lectures and information that benefit the students on their websites.

According to the study results, the faculty staff members have positive attitudes towards the benefit of modern teaching technologies to faculty staff and student, except for uploading lectures on their websites (61.5\%) (f: 80) answered with (Disagree), while only (17.7\%) (f: 23) answered with (Agree), urging their students to browse their website $(50.8 \%)$ (f: 66) answered with (Disagree), while only (23.8\%) (f: 30) answered with (Agree).

\section{The fourth aspect: The technology infrastructure}

The technology infrastructure consisted of five questionnaire items $(10,14,24,28$, and 29). Mean and standard deviation for the fourth aspect items (The benefit of modern teaching technologies to faculty staff and student) were analysed. Table (5) displayed the Mean and standard Deviation analysis. 
Table (5): Mean and Standard Deviation Analysis of Technology Infrastructure

\begin{tabular}{llcc}
\hline No. & \multicolumn{1}{c}{ Item } & Mean & $\begin{array}{c}\text { Standard } \\
\text { Deviation }\end{array}$ \\
\hline $1 . \quad \begin{array}{l}\text { Data projector is an } \\
\text { important devices in the } \\
\text { classroom }\end{array}$ & 2.91 & 0.29 \\
2. $\quad \begin{array}{l}\text { The Internet is available in } \\
\text { the lecture rooms }\end{array}$ & 1.29 & 0.70 \\
3. $\quad$ The classrooms were \\
$\begin{array}{l}\text { equipped with data } \\
\text { projectors } \\
\text { The classroom were } \\
\text { equipped with electrical }\end{array}$ & 2.23 & 0.96 \\
$\begin{array}{l}\text { connections } \\
\text { Classrooms contain } \\
\text { platforms for laptops }\end{array}$ & 1.88 & 0.91 \\
\hline
\end{tabular}

Table (5) showed values of standard deviation \& Mean for the technology infrastructure. The biggest mean value (2.91) and standard deviation (0.29) is for participants who see that data projector is an important devices in the classroom. The second biggest mean value (2.35) and standard deviation (0.91) is participants who see that, the classrooms were equipped with electrical connections. The third biggest mean value (2.23) and standard deviation (0.96), is for those who see that, the classrooms were equipped with data projectors. The fourth biggest mean (1.88) and standard deviation (0.90) is for the participants who mentioned that, the classrooms contained platforms for laptops. The fifth biggest mean (1.29) and standard deviation (0.70) is for the participants who stated that, the Internet is available in the lecture rooms.

It is clear from the above that college of education, Jazan university have the infrastructure for modern technologies, except the availability of the Internet in lecture rooms (84.6\%) (f: 110) of participants who answered with (Disagree), while only (13.8\%) (f: 18) of them answered with (Agree), and the availability of platforms in the classrooms (46.9\%) (f: 61) of the participants answered with (Disagree), while (35.4\%) (f: 46) were answered with (Agree).

\section{The fifth aspect: Obstacles to use}

The Obstacles to use consisted of four questionnaire items (20, 32, 35, and 37). Mean and standard deviation for the fifth aspect items (The Obstacles to use of modern teaching technologies in educational process) were analysed. Table (6) displayed the mean and standard deviation analysis.

Table (6) : Mean and Standard Deviation Analysis for Obstacles to Use

\begin{tabular}{llcc}
\hline N0 & \multicolumn{1}{c}{ Item } & $\begin{array}{c}\text { Mea } \\
\mathbf{n}\end{array}$ & $\begin{array}{c}\text { Standard } \\
\text { Deviation }\end{array}$ \\
\hline 1. & $\begin{array}{l}\text { E-mail takes a lot of } \\
\text { my time }\end{array}$ & 1.89 & 0.72 \\
& & \\
2. $\quad \begin{array}{l}\text { The use of modern } \\
\text { teaching technologies } \\
\text { adds a burden to the } \\
\text { faculty member }\end{array}$ & 1.72 & 0.71 \\
$\begin{array}{l}\text { The use of modern } \\
\text { teaching technologies } \\
\text { in teaching wastes a } \\
\text { lot of my time }\end{array}$ & & \\
& & \\
\end{tabular}

Table (6) showed values of standard deviation \& Mean for the obstacles to use. The biggest mean value (1.89) and standard deviation (0.72) is for participants who see that, e-mail takes a lot of their times. The second biggest mean value (1.72) and standard 
deviation (0.71) is participants who see that, the use of modern teaching technologies adds a burden to the faculty member. The third biggest mean value (1.60) and standard deviation (0.72), is for those who see that, the use of modern teaching technologies in teaching wastes a lot of their times.

According to the study results, the faculty staff members have positive attitudes towards obstacles to use. That means, most of the participant stated that, there were no obstacle to use of modern technologies in educational process.

So, according to the results of participant responses to the questionnaire aspects, the study participants have a positive attitude towards the use of modern teaching technologies in the educational process.
The second hypothesis: There are no significant differences at the level of significance (0.05) between faculty staff responses on the impact of the use of modern teaching technologies in the educational process, related to gender variable.

$$
\begin{aligned}
& \text { H0: } \mu 1=\mu 2 \\
& \text { HA: } \mu 1 \neq \mu 2
\end{aligned}
$$

This hypothesis aimed to indicate whether the gender variable has an impact on faculty staff members attitudes towards the use of modern teaching technologies in the educational process. To test this hypothesis, the T-test was used for the difference between two independent sample averages and the results were shown in Table (7).

\begin{tabular}{|c|c|c|c|c|c|c|c|c|c|}
\hline \multirow[t]{2}{*}{ Gender } & \multirow[t]{2}{*}{$\mathrm{N}$} & \multirow[t]{2}{*}{ Mean } & \multirow{2}{*}{$\begin{array}{c}\text { Std. } \\
\text { Deviation }\end{array}$} & \multirow[t]{2}{*}{$\mathrm{t}$} & \multirow[t]{2}{*}{$\mathrm{df}$} & \multirow{2}{*}{$\begin{array}{c}\text { Sig. } \\
\text { (2 tailed) }\end{array}$} & \multicolumn{2}{|c|}{$\begin{array}{c}\text { 95\% confidence } \\
\text { Interval } \\
\end{array}$} & \multirow[t]{2}{*}{ Sig. } \\
\hline & & & & & & & Lower & Upper & \\
\hline Male & 21 & 3.62 & 0.59 & 4.047 & 51.781 & 0.000 & 0.339 & 1.008 & Sig. \\
\hline Female & 109 & 2.95 & 1.10 & & & & & & \\
\hline
\end{tabular}

Table (7): Mmeans \& Std. Deviation \& T-Test Values of Study Participants

Table (7) showed that the mean value of males' attitudes towards the impact of the use of modern teaching technologies in the educational process (3.62), whereas the females' mean value is (2.95). The calculated $t$ value is (4.047) which is bigger than statistical table t value (2.000), df (51.781). As Cal t > Tab t, and Sig. (2-tailed) (0.000) is less than 0.025. This indicated that there were significant differences at the level of significance (0.05) between male and female participants in favor of male participants. Thus, the null hypothesis (H0: $\mu 1=\mu 2)$ was rejected and alternative (HA: $\mu 1 \neq \mu 2)$ was accepted.
The third hypothesis: There are no significant differences at the level of significance $(0.05)$ between faculty staff responses on the impact of the use of modern teaching technologies in the educational process, related to experience variable.

$$
\begin{aligned}
& \text { H0: } \mu 1=\mu 2=\mu 3 \\
& \text { HA: } \mu 1 \neq \mu 2 \neq \mu 3
\end{aligned}
$$

This hypothesis aimed to indicate whether the experience variable has an impact on faculty staff members attitudes towards the use of modern teaching technologies in the educational process, related to experience variable. To test this hypothesis, the One ANOVA Test was used. Table (8) showed 
means and standard deviation values of the study participants.

Table (8): The Table Present the Means \& Std. Deviation Values of Study Participants

\begin{tabular}{|c|c|c|c|c|c|}
\hline \multirow[t]{2}{*}{ Variable (Experience) } & \multirow[t]{2}{*}{$\mathbf{N}$} & \multirow[t]{2}{*}{ Mean } & \multirow[t]{2}{*}{ Std. Deviation } & \multicolumn{2}{|c|}{ 95\% Confidence Interval } \\
\hline & & & & Lower & Upper \\
\hline Less than 5 years & 41 & 1.92 & 0.264 & 1.843 & 2.010 \\
\hline $5-10$ years & 21 & 1.66 & 0.483 & 1.447 & 1.886 \\
\hline More than 10 years & 68 & 1.93 & 0.271 & 1.848 & 2.028 \\
\hline
\end{tabular}

Table (8) showed the mean \& std. deviation values of study participants' attitudes towards the use of modern teaching technologies in the educational process, related to experience variable. The mean value of participants who have more than 10 yeas' experience reached (1.93), whereas the mean value of the participants who have experience less than 5 years reached (1.92), and the mean value of participants who have from 5-10 years' experience reached (1.66), so, as showed in table (8), $\mu 1 \neq \mu 2 \neq \mu 3$. To verify this result, one-way ANOVA test was used, as appeared in Table (9).

Table (9): The Table Presents One Way Anova Test to Find Out Differences Between Study Participants According to Experience Variable

\begin{tabular}{|c|c|c|c|c|c|}
\hline $\begin{array}{c}\text { Sources of } \\
\text { contrast }\end{array}$ & $\begin{array}{l}\text { Sum of } \\
\text { squares }\end{array}$ & $\mathrm{df}$ & $\begin{array}{c}\text { Mean } \\
\text { squares }\end{array}$ & $\mathrm{F}$ & Sig. \\
\hline $\begin{array}{l}\text { Between } \\
\text { groups }\end{array}$ & 0.940 & 2 & 0.470 & 3.581 & 0.031 \\
\hline $\begin{array}{l}\text { Within } \\
\text { groups }\end{array}$ & 16.668 & 127 & 0.131 & & \\
\hline Total & 17.608 & 129 & & & \\
\hline
\end{tabular}

Table (9) showed calculated (Cal) (F) value as an indication of differences between the study participants attitudes towards the use of modern teaching technologies in the educational process, related to experience variable. Cal $(\mathrm{F})$ value was (3.581), whereas (F) value that derived from statistical table (Tab) was (2.995). Since Cal (F) value $>$ Tab (F) value, and also level of significant adopted for this study $(0.05)>(0.031)$. Thus, the null hypothesis (H0) (There are no significant differences at the level of significance $(0.05)$ between the study participants attitudes towards the use of modern teaching technologies in the educational process, related to experience variable) was rejected. Once the null hypothesis was rejected, we have to determined which of the means is not equal, to verify this, comparison differences was used to compare each two mean values together, the hypotheses for this is as follows:

$\mathrm{H} 0: \mu \mathrm{i}=\mu \mathrm{j}$

HA: $\mu \mathrm{i} \pm \mu \mathrm{j}, \mathrm{i}<\mathrm{j}=1,2,3$ 
Table (10): The Table Presents Multiple Comporision To Compare Mean Values Together

\begin{tabular}{|c|c|c|c|c|c|c|c|}
\hline & \multirow[t]{2}{*}{ Experience(i) } & \multirow[t]{2}{*}{ Experience(j) } & \multirow[t]{2}{*}{$\begin{array}{c}\text { Mean } \\
\text { difference }(i-j)\end{array}$} & \multirow[t]{2}{*}{$\begin{array}{l}\text { Std. } \\
\text { Error }\end{array}$} & \multirow[t]{2}{*}{ Sig. } & \multicolumn{2}{|c|}{$\begin{array}{c}\text { 95\% Confidence } \\
\text { Interval }\end{array}$} \\
\hline & & & & & & Lower & Upper \\
\hline \multirow[t]{6}{*}{ LCD } & Less than 5 years & $5-10$ years & $0.260^{*}$ & 0.972 & 0.008 & 0.068 & 0.453 \\
\hline & & $\begin{array}{c}\text { More than } 10 \\
\text { years }\end{array}$ & 0.088 & 0.072 & 0.218 & -0.053 & 0.230 \\
\hline & $5-10$ years & Less than 5 years & $-0.260^{*}$ & 0.972 & 0.008 & -0.453 & -0.618 \\
\hline & & $\begin{array}{c}\text { More than } 10 \\
\text { years }\end{array}$ & $-0.272^{*}$ & 0.904 & 0.006 & -0.351 & 0.007 \\
\hline & $\begin{array}{l}\text { More than } 10 \\
\text { years }\end{array}$ & Less than 5 years & -0.088 & 0.072 & 0.218 & -0.230 & 0.053 \\
\hline & & 5-10 years & $0.272^{*}$ & 0.904 & 0.006 & -0.007 & 0.351 \\
\hline
\end{tabular}

*The mean difference is significant at the (0.05) level

Table (10) showed the comparison mean values, which compared each two mean values together to determine which is significance. The researcher notice that: The differences between mean values of (Less than 5 years) group and (5-10 years) group is significance. The difference between mean values of (Less than 5 years) group and (More than 10 years) group is not significance. The difference between mean values of (5-10 years) group and (More than 10 years) group is significance.

The fourth hypothesis: There are no significant differences at the level of significance $(0.05)$ between faculty staff responses on the impact of the use of modern teaching technologies in the educational process, related to computer training variable.

$$
\begin{aligned}
& \text { H0: } \mu 1=\mu 2=\mu 3 \\
& \text { HA: } \mu 1 \neq \mu 2 \neq \mu 3
\end{aligned}
$$

(or at least two means are not equal)

This hypothesis aimed to indicate whether the computer training variable has an impact on faculty staff members attitudes towards the use of modern teaching technologies in the educational process. To test this hypothesis, the ANOVA test was used. Table (11) showed means and standard deviation values of the study participants.

\begin{tabular}{|c|c|c|c|c|c|}
\hline \multirow[t]{2}{*}{ Variable } & \multirow[t]{2}{*}{$\mathbf{N}$} & \multirow[t]{2}{*}{ Mean } & \multirow[t]{2}{*}{ Std. deviation } & \multicolumn{2}{|c|}{ 95\% Confidence Interval } \\
\hline & & & & Lower & Upper \\
\hline No computer training found & 16 & 2.00 & 0.000 & 2.000 & 2.000 \\
\hline One computer training course & 22 & 1.95 & 0.213 & 1.860 & 2.049 \\
\hline $\begin{array}{l}\text { Two computer training } \\
\text { courses }\end{array}$ & 31 & 1.81 & 0.402 & 1.059 & 1.953 \\
\hline More than two courses & 61 & 1.77 & 0.424 & 1.662 & 1.879 \\
\hline
\end{tabular}

Table (11): The Table Presesnts The \& Std. Deviation Values of Study Participants 
Table (11) showed that, there is a large convergence between the mean values of study participants' attitudes towards the use of modern teaching technologies in the educational process, due to computer training courses. The mean value of the participants who were not attended any computer course reached (2.00), whereas the mean value of participants who attended one computer course reached (1.95), and the mean value of participants who attended two computer courses reached (1.81), and the mean value of participants who attended more than two computer courses reached (1.77). To verify this result, one-way ANOVA test was used, as appears in Table (12).

Table (12): The Table Presents One Way Anova Test to Find Out Differences Between Study Participants According to Age Variable

\begin{tabular}{lccccc}
\hline $\begin{array}{c}\text { Sources of } \\
\text { contrast }\end{array}$ & $\begin{array}{c}\text { Sum of } \\
\text { squares }\end{array}$ & df & $\begin{array}{c}\text { Mean } \\
\text { squares }\end{array}$ & F & Sig. \\
\hline $\begin{array}{l}\text { Between } \\
\text { groups }\end{array}$ & 1.028 & 3 & 0.343 & 2.603 & 0.055 \\
Within & 16.580 & 126 & 0.132 & & \\
$\begin{array}{l}\text { groups } \\
\text { Total }\end{array}$ & 17.608 & 129 & & & \\
\hline
\end{tabular}

Table (12) showed calculated (Cal) (F) value as an indication of differences between the study participants attitudes towards the use of modern teaching technologies in the educational process due to computer training courses. Cal (F) value was (2.603), whereas (F) value that derived from statistical table (Tab) was (2.995). Since Tab (F) value $>$ Cal $(F)$ value, and also level of significant adopted for this study $(0.05)<(0.055)$. Thus, the null hypothesis (H0) (There are no significant differences at the level of significance (0.05) between the study participants attitudes towards the use of modern teaching technologies in the educational process, due to computer training courses) was accepted.

\section{IV.CONCLUSION}

Personal data of the faculty staff members was analysed. (83.8\%) of the study participants were female staff members; (66.2\%) of participants were Ph. D. holders; (57\%) of participants were science specialization; (64.6\%) of participants were faculty staff who related to the field of education; (53.8\%) of the participant were assistant professors; (53.3\%) of study participants were had experience more than five years; (46.9\%) of the participants were attended more than two computer training courses; (36.2\%) of the participants attended more than two technology training courses.

According to the participants' responses to the questionnaire aspects, the study participants have a positive attitudes towards the use of modern teaching technologies in the educational process.

There are significant differences at the level of significance (0.05) between faculty staff responses on the impact of the use of modern teaching technologies in the educational process in favor of male participants. Thus, the null hypothesis (H0: $\mu 1=\mu 2)$ was rejected.

There are significant differences at the level of significance (0.05) between the study participants' attitudes towards the use of modern teaching technologies in the educational process, related to experience variable. Thus. The null hypothesis was rejected. 
There are no significant differences at the level of significance (0.05) between the study participants' attitudes towards the use of modern teaching technologies in the educational process, due to computer training courses. Thus, the null hypothesis (H0) was accepted.

The researcher concluded that, faculty staff members have a positive attitude towards the usage of modern teaching technologies in the educational process.

\section{RECOMMENDATIONS}

Modern teaching techniques are a vital technique in the teaching and learning process. In order for faculty staff members to make effective use of them, they must be involved in appropriate training programs.

Although the use of modern teaching technologies is inexpensive, there are still faculty staff members who are unable to use them in the classroom.

The learning environment needs more attention and more facilities so that a faculty staff member can use modern teaching techniques in the classroom.

\section{VI.REFERENCES}

[1]. Ajlooni, K. (2009). The reality of use of ICT by graduate students in the Faculty of Educational Sciences at the University of Jordan (Ph. D. Thesis). Studies, Educational Sciences, vol. 36, (Annex), 2009. Retrieved from https://journals.ju.edu.jo/DirasatEdu/article/do wnload/689/687

[2]. Al-Nadawi, F. (2012). Educational Techniques and Their impact in Developing Methodologies of Physical Education in Higher Education. Journal of the University of Kirkuk for Humanitarian Studies Volume: 7, Issue: 3. Retrieved

from
http://alkhbraa.com/home/PDFs/rasael/techinfo/

[3]. Cuban, L. (2003) Oversold and underused: Computers in the classroom. Cambridge, MA: Harvard University Press.

[4]. Dreaweesh, A. (2003). The impact of using multimedia on the achievement of the secondgrade intermediate students in science subject in Al- Riyadh city, Saudi Arabia (Master Thesis). Retrieved from http://alkhbraa.com/home/PDFs/rasael/techinfo

[5]. Eady, M. J. \& Lockyer, L. (2013). 'Tools for learning: technology and teaching strategies', Learning to Teach in the Primary School, Queensland University of Technology, Australia. pp. 71.

[6]. Hassett, J. M.; Spuches, C. M.; and Webster, S. P., "Using Electronic Mail for Teaching and Learning" (1995). To Improve the Academy. 333.

http://digitalcommons.unl.edu/podimproveacad /333

[7]. Hew, K. F. \& Brush, T. (2007). Integrating technology into $\mathrm{K}-12$ teaching and learning: Current knowledge gaps and recommendations for future research. Educational Technology Research \& Development, 55(3), 22-52.

[8]. Mohamed, M. (2013). Attitudes of faculty members towards the use of means and techniques of e-learning and its relation to some variables - Faculty of Education Hantoub - University of the Gezira - Sudan. Gezira Journal for Educational and Human Sciences Volume (10) No. (2), pp. 5-34.

[9]. Mueller, J., Wood, E., Willoughby, T., Ross, C. \& Specht, J. (2008). Identifying discriminating variables between teachers who fully integrate computers and teachers with limited 
integration. Computers and Education, 51(4), 23-37.

[10]. Nagel, D. (2018). Most Teaching and Learning Uses Technology Nowadays. Retrieved from https://thejournal.com/articles/2018/07/10/stud $\mathrm{y}$-most-teaching-and-learning-usestechnology-nowadays.aspx? $\mathrm{m}=1$

[11]. Lateh, H. \& Raman, A. (2005). A Study on the Use of Interactive Web-Based Maps in the Learning and Teaching of Geography, Malaysian Online Journal of Instructional Technology (MOJIT), 2 (3), 99-105.

[12]. Sadat, A. \& Rahman, K. (n. d.). Prospect of Email Communication as an Educational Tool for Distance Education in Bangladesh. Retrieved August 5, 2015 from http://www2.uwstout.edu/content/lib/thesis/20 08/2008youngr.pdf

[13]. Sezer, A. (2010). Geography teachers' usage of the INTERNET for the education purposes. International Journal of Progressive Education, 6(3), 38-50.

[14]. Young, R. (2008). Using technology tools in the public school classroom (Master dissertation). Retrieved from: http://www2.uwstout.edu/content/lib/thesis/20 08/2008youngr.pdf

\section{Cite this article as :}

Mahasin Gad Alla Mohamed, "The Impact of the use of Modern Teaching Technologies (MTT) In Educational Process at the Faculty of Education, Jazan University ", International Journal of Scientific Research in Science and Technology (IJSRST), Online ISSN : 2395-602X, Print ISSN : 2395-6011, Volume 6 Issue 5, pp. 01-17, September-October 2019. Available at doi :

https://doi.org/10.32628/IJSRST196471

Journal URL : http://ijsrst.com/IJSRST196471 